\title{
O instrumentach, narzędziach, przyrządach, przyborach w językach słowiańskich
}

Tematycznie niniejszy artykuł $\mathrm{w}$ pewnym stopniu wiąże się z przygotowywaną przeze mnie monografią o nazwach instrumentów muzycznych w języku bułgarskim. Celem jego jest ukazanie nazewnictwa dla pojęcia 'instrumentum' w poszczególnych językach słowiańskich, zaczynając od bułgarskiego i polskiego.

$\mathrm{W}$ odniesieniu do języka polskiego zagadnienie to omawiane jest $\mathrm{w}$ artykule Aleksandra Zajdy pt. Historia pola wyrazowego 'instrumentum' w języku polskim. Autor wspomina m.in. o staropolskich wyrazach (wg Słownika staropolskiego), które funkcjonują w płaszczyźnie hiperonimii pola 'instrumentum' takich, jak statek, strój, naczynie, naczyn. Sygnalizuje, że w staropolszczyźnie największą frekwencję miało naczynie a następnie strój. Autor omawia ich pochodzenie. Wspomina też o innych bliskoznacznych nazwach takich, jak przyprawa, nastrój, narząd. Jednocześnie zaznacza, że w XVII wieku w znaczeniu 'instrumentum' funkcjonują: instrument, narzędzie, naczynie, statek, przy czym ten ostatni nie we wszystkich tekstach. Jednocześnie pojawia się niemiecka nazwa cajg a także coraz szerzej używany jest wyraz sprzęt. W XVIII wieku naczynie jest już coraz rzadziej używane w znaczeniu 'instrumentum', a głównie w znaczeniu 'vas, vasa'. Na koniec autor stwierdza, że wyszły z użycia wyrazy polisemiczne: instrument, naczynie, statek, a ostały się monosemiczne: narzędzie, przyrząd, przybory. Nie mogę się z au- 
torem zgodzić co do eliminacji wyrazu instrument, gdyż w pewnych kontekstach funkcjonuje on nadal, nie tylko jako muzyczny, ale także medyczny - zabiegowy (instrumenty chirurgiczne, dentystyczne, laryngologiczne itp.). W każdym razie artykuł ten jest jedną $\mathrm{z}$ ważniejszych pozycji w literaturze przedmiotu $^{1}$. Należy dodać, iż wymienione przez autora nazwy strój, nastrój funkcjonują dziś w znaczeniu 'instrumentum' (lub bliskim) w języku czeskim, o czym będzie wspomniane w niniejszym artykule.

Rozważania zaczniemy od wyrazu instrument. Pochodzi on $\mathrm{z} ł a c$. instrūmentum 'inwentarz, sprzęt, wyposażenie, rynsztunek, narzędzie, środek pomocniczy; nauka, pouczenie'2, a to od czasownika instruere 'budować, wystawiać, wznosić, tworzyć; urządzać; wykonywać, spełniać; zamyślać, obmyślać, knućs ${ }^{3}$ Instrument jest wyrazem międzynarodowym, por. ang., franc. instrument itd.

W języku bułgarskim rzeczownik инструмент posiada szeroki zakres znaczeniowy. Według słownika języka bułgarskiego Bułgarskiej Akademii Nauk $^{4}$ znaczenie wyrazu инструмент jest następujące: 1 . ръчно оръдие ${ }^{5}$, уред за извършване на някаква работа 'ręczne narzędzie, przyrząd do wykonywania jakiejś pracy': По масата бяха разпилени какви ли не инструменти - пили, чукове, свредели, отверки; Хирургическите инструменти; 2. уред, устройство с някакво предназначение, възможности 'przyrząd, urządzenie służące do czegoś: Точни измервания с чувствителни инструменти показват, че тези напрежения не са постоянни, а се менят с течение на времето; 3. [przen.] средство за постигане на някаква цел 'środek do osiągnięcia jakiegoś celu’: В политическите процеси имено най-ярко се вижда, как правосъдието се използува като инструмент на политика$m a ; 4$. [zawężone] музикален инструмент 'instrument muzyczny': A щом другите инструменти замлькваха и само кларнетьт зареждаше някоя

${ }^{1}$ A. Z aj d a, Historia pola wyrazowego 'instrumentum' w jezzyku polskim, [w:] Dzieje Słowian w świetle leksyki. Pamięci Profesora Franciszka Sła wskiego, red. W. B o r y ś, J. R u s ek, Kraków 2002, s. 363-373. Ten sam autor zajmuje się pochodzeniem, znaczeniem i historią nazw kilku narzędzi ciesielsko-stolarskich w artykule pt. $Z$ historii nazw narzędzi do obróbki drewna: strug, hebel, rzezak, ośnik, [w:] Studia linguistica in honorem Stanislai Stachowski, red. E. Mań c zak-Wohlfeld, Kraków 2000, s. 167-175.

${ }^{2}$ Por. pol. instrukcja, instruktor.

${ }^{3}$ Zob. A. B á́kow ski, Etymologiczny słownik języka polskiego, Warszawa 2000, t. I, s. 531 (dalej: Bańkowski); M. Ple zi a, Słownik łacińsko-polski, Warszawa 1998, t. III, s. 206.

${ }^{4}$ Речник на българския език, ред. К. Чола ков а, София 1977 i n. (dalej: RBE).

${ }^{5} \mathrm{~W}$ dzisiejszej bułgarszczyźnie wyraz ten używany jest głównie w znaczeniu 'armata, działo. 
тъжна мелодия, тогава той виждаше узрели жита. Słownik ten podaje także zestawienia: музикални инструменти [muz.] уреди за произвеждане на звуци с определена височина или на някои шумове без определена височина, но с определен характерен тембър 'urządzenia do emisji dźwięków o określonej wysokości lub szumów bez określonej wysokości, ale o określonej barwie, instrumenty тиzусzпе' oraz шанцов инструмент [wojsk.] специална лопата с къса дръжка, използувана за окопаване при военни действия 'specjalna łopata o krótkim stylisku, używana do okopywania się podczas działań wojennych, saperka'.

Zakres znaczeniowy rzeczownika instrument $\mathrm{w}$ języku polskim jest znacznie węższy. Słownik współczesnego języka polskiego pod red. Bogusława Dunaja ${ }^{6}$ definiuje to następująco: 1 . przyrząd, na którym można zagrać melodię, wytwarzać dźwięki muzyczne, muzykować, np. fortepian, gitara, flet. Instrument muzyczny. Dobry muzyk gra na kilku instrumentach. Potrafit akompaniować nawet na kiepskim instrumencie. 2. zwykle precyzyjny przyrząd lub urządzenie, którym wykonuje się prace wymagające dokładności. Instrumenty lekarskie, pomiarowe ${ }^{7}$. 3. coś, za pomocą czego można osiągnąć zamierzony cel; środek, metoda działania. Instrumenty władzy. Podobnie definiuje znaczenie tego wyrazu słownik pod red. Mieczysława Szymczaka ${ }^{8}$, przy czym przy trzecim znaczeniu daje kwalifikator przen. Bułgarski wyraz инструмент ma więc szerszy zakres semantyczny, obejmujący znaczenia polskich rzeczowników narzędzie, przyrzą, instrument. Niemniej jednak język bułgarski dla oddania pol. 'narzędzie' zna także słowiański wyraz opzдue, który jest wieloznaczny. Posiada on następujące znaczenia: 1. техническо приспособление, с чиято помощ се извършва някаква работа или действие; уред, инструмент, сечиво 'urządzenie techniczne, za pomocą którego wykonuje się pewne prace lub czynności, narzędzie, urządzenie’: Нашето селско стопанство енегодно се снабдява все повече с мошни високопроизводителни трактори и сложни селскостопански машини и оръдия. 2. [przen.] лице или група хора, които действат по чужда воля и в чужда полза 'osoba (-y), która działa według cudzej woli i dla czyjejś korzyści': Атрактивна избирателна кампания, която провеждат, е добро орғдие за активизиране на населението. 3. [wojsk.] тежко огнестрелно оръжие [...] голяма далекобойност [...] 'ciężka broń palna [...] о dużym

${ }^{6}$ Słownik współczesnego języka polskiego, red. B. D u n a j, t. 1-2, Warszawa 1999 (dalej: Dunaj).

${ }^{7} \mathrm{O}$ urządzeniach pomiarowych raczej się w języku polskim mówi przyrządy.

${ }^{8}$ Słownik języka polskiego, red. M. S z y m c z a k, t. I-III, Warszawa 1978-1981 (dalej: SJP). 
zasięgu, armata, działo': На военната комисия казах, че имам желание да бъда артилерист, обаче ... ме пратиха в пехотен полк. И наистнина не бях добър войник, защото имах желание да стрелям не с автомат, а с оръдиe (RBE: 11). Współcześnie wyraz ten jest najczęściej używany w tym ostatnim, wojskowym znaczeniu (synonimem jest turcyzm mon). Co się tyczy znaczenia 'narzędzie', to z przykładu wynika, iż bułg. opzdue oznacza narzędzie do wykonywania ciężkich, „topornych”, prostych prac (np. uprawa ziemi, roboty ciesielskie itp.), a do bardziej precyzyjnych służy инструмент. Także przemawia za tym synonim сечиво 'narzędzie", etymologicznie wspólny z pol. siekiera. Odpowiednikiem wyrazu opъdue w języku polskim jest orędzie, niemniej jednak ma zupełnie inne znaczenie, mianowicie 'uroczyste wystąpienie, przemówienie, posłanie, zwykle głowy państwa lub dostojnika kościelnego, skierowane do ogółu i dotyczące spraw wielkiej wagi', orędzie noworoczne, orędzie do narodu, wystosować orędzie.

Bułg. opzdue (i pol. orędzie) to wyrazy ogólnosłowiańskie, por. sch. òruđe 'narzędzie, przyrząd, sprzęty, utensylia, 'działo'; słń. orôd, orôdje; czes. orudí 'narzędzia, instrumenty, broń'; ros. opydue 'narzędzie,' 'działo'; ukr. opỳda 'robota, praca'; scs. ордане 'rzecz, sprawa, czyn'; strus. opor_нне 'rzecz, sprawa, czyn, praca, narzędzie, oręż. Prasłowiańskie *orodbje, collectivum do *orodz (poświadczone w słoweńskim) $<o(b)$ orǫd $/ / o(b)$ oroda 'doglądanie czegoś, kierowanie czymś; to, co jest uporządkowane, przygotowane do czegoś; to, co służy do przygotowania czegoś, narzędzie, instrument, naczynie', a to ostatnie jest rzeczownikiem dewerbalnym (przedrostkowym) od ${ }^{\star}$ ob-ręditi 'ustawiać w szeregu, szeregować, porządkować, kierować czymś, rządzić, władać, $\mathrm{z}$ właściwą archaicznym rzeczownikom wymianą samogłoski rdzennej $e$ : $o$. Specyficzne polskie znaczenia 'posłowanie, misja poselska, oznajmienie, wiadomość rozwinęły się zapewne $\mathrm{z}$ wcześniejszego 'to, co służy do doglądania czegoś, kierowania, zarządzania czyms' ${ }^{\prime 10}$.

Rzeczownik оръжиe ma w języku bułgarskim ogólne znaczenie 'broń, uzbrojenie' a także znaczenie [wojsk.] 'rodzaj broni', np.: В какъв род оръжие ти си служил? В артилерията oraz 'wojsko, armia': Повече задръжки за победилото руско оръжие не може да има (oraz przen. 'środki walki') (RBE: 11). Odpowiednikiem polskim jest oręż mające to samo znaczenie: 1. broń, uzbrojenie, Ich oręż składat się z włóczni na długim drzewcu i drew-

9 Tak tłumaczy wyraz сечиво Franciszek Sławski (por. Podręczny słownik bułgarsko-polski, Warszawa 1963). Bardziej trafne byłoby 'narzędzie ciesielskie', 'siekiera'.

10 Zob. W. B or yś, Słownik etymologiczny języka polskiego, Kraków 2005, s. 395 (dalej: Boryś SE). 
nianej tarczy; 2. wojsko, wojskowość, Chwała oręża polskiego; 3. środki wykorzystane do osiągnięcia jakiegoś celu, narzędzie, sposób, metoda, służące do przeciwstawiania się komuś lub czemuś, pokonywania kogoś lub czegoś, Literatura była niezawodnym orężem $w$ walce o zachowanie polskości $w$ czasach zaborów ${ }^{11}$.

Wbrew pozorom, bułg. орғдие i оръжие (podobnie jak i polskie orędzie i oręż) nie są wyrazami spokrewnionymi. Mimo bliskoznaczności w niektórych językach słowiańskich (np. bułg. opzжue 'broń, uzbrojenie' / opzdue 'armata, działo' wywodzą się z innej postaci prasłowiańskiej. Oręż pochodzi z psł. ${ }^{\star} o(b)$ rǫ̌žje 'wyposażenie, sprzęty, narzędzia, zwłaszcza narzędzia walki, broń' (scs. оржжнє 'oręż, broń, miecz'), które jest pierwotnym collectivum z przyrostkiem *-bje od hipotetycznego, słabo udokumentowanego rzeczownika ${ }^{\star} o(b)$ roga 'ubiór, strój' (zachowane tylko w ros. dial. oбpyzza 'tradycyjny świąteczny strój, strój ludowy; ludowe nakrycie głowy'). Bliskie jest lit. aprangà 'ubiór, strój' od czasownika przedrostkowego ap-reñgti 'ubierać, co jest pokrewne $\mathrm{z}$ lit. rangà 'obstalunek' a także śrwysniem. ranc 'szybki ruch wirowy', niem. sich ranken 'piąć się, wić się'. Podstawą tych wyrazów byłoby pie. *çreng- 'obracać, kręcić', od pierwiastka *çer- 'kręcić, zginać, wyginać' (Boryś SE 395-296). Holub-Kopečný uważa, że jest to kontaminacja z ps. *orǫdbje, niemniej jednak inni autorzy (np. Vasmer) uważają taką etymologię za niemożliwą: „неприемлемо сближение с орудие и объяснение из др.сакс ärundi, д.-в.-н. ārunti"'12.

$\mathrm{Z}$ bułgarskim opъdue i pol. orędzie etymologicznie spokrewnione jest pol. narzędzie. Jak pisze A. Bańkowski, pierwotnie było to sg. tantum o znaczeniu 'przybory, zbiór instrumentów', np. wszystko wojenne narzędzie (1582 r.; także przen. 'środek działania') i było collectivum do narząd. Z czasem narzędzie nazywało pojedynczy instrument, stąd. pl. narzędzia. Narząd pierwotnie oznaczał 'narzędzie, instrument (muzyczny)', a w znaczeniu biologicznym 'organ, część organizmu żywego pełniąca osobą funkcję' występuje dopiero od XIX wieku (dziś jest to jedyne jego znaczenie). Wywodzi się z ps. "narędz 'to, co jest przygotowane, przystosowane do czegoś' i jest rzeczownikiem dewerbalnym od ps. czasownika przedrostkowego ${ }^{*}$ na-ręditi 'uporządkować, przystosować do czegoś, przygotować' < 'ręditi, ręd’o 'usta-

${ }^{11}$ Por. Dunaj; warto przytoczyć też fragment pieśni: Gdy naród do boju wystąpił z orężem, panowie $w$ stolicy radzili....

12 Za M. Ф а сме р, Этимологический словарь русского языка, Перевод с немецкого и дополнения О.Н. Труб б ч в в а, т. III, Москва 1971 (dalej: Vasmer); Български етимологичен речник, ред. В.И. Ге о рг и ев, И. Дур и да н о в, т. 4, София 1995, s. 931 (dalej: BER). 
wiać w szeregu, szeregować, porządkować, wprowadzać ład, doglądać czegoś, kierować czymś, rozporządzać, rządzić, władać' a to od ps. *rędz 'szereg, rząd' > 'miejsce w szeregu, uporządkowanie, porządek, ład', które jest pokrewne $\mathrm{z}$ lit. rindà 'rząd, linia', łot. rinda 'ts.' (motywacja czasownikowa na gruncie bałtyckim: łot. rist, riedu 'doprowadzać do porządku'). Prawdopodobnie pochodzi z pie. ${ }^{*}$ rnd-o- 'uporządkowanie, porządek', ${ }^{\star} r e n d-$ 'porządkować' (Boryś SE 352, 531; Bańkowski II, 271, 272).

Słownik współczesnego języka polskiego pod red. Bogusława Dunaja definiuje znaczenie wyrazu narzędzie następująco: 1 . każdy przedmiot umożliwiający lub ułatwiający wykonanie jakiejś pracy; przyrząd, instrument. Narzędzie ręczne, mechaniczne. Narzędzia murarskie, stolarskie, medyczne. Narzędzie tortur, zbrodni. Program będacy doskonatym narzędziem do odzyskiwania utraconych plików. 2. osoba będąca najczęściej nieświadomym wykonawcą czyjejś woli, planów. Być narzędziem w czyichś rękach. To drugie znaczenie należy potraktować jako przenośne (słownik nie opatruje go żadnym kwalifikatorem).

Etymologicznie z powyższymi wyrazami spokrewniony jest pol. przyrząd, niemający dokładnego strukturalnego odpowiednika w języku bułgarskim. Pierwotne znaczenie to nomen actionis 'przyrządzenie', później (II poł. XIX w.) 'aparat służący do przyrządzania czegoś. Pochodzi od przyrządzić, a to z ps. ${ }^{*}$ pri-ręditi (o etymologii ${ }^{*}$ ręditi zob. wyżej). Przedrostek przy- (ps. ${ }^{*}$ pri-) w swej funkcji pierwotnej jest bliskoznaczny $\mathrm{z}$ do-, np. przybudować : dobudować, przyczepić : doczepić. Prefiks ten jest semantycznym wykładnikiem motorycznej relacji zbliżenia całkowitego ( $\mathrm{z}$ osiągnięciem kontaktu w przestrzeni lub czasie) (Bańkowski I 276-277; II 928, 948). Czyli przyrządzić oznaczałoby pierwotnie 'uporządkować, uszeregować do końca', stąd rozwój znaczenia 'zrobić coś, wykonać coś do końca' (we współczesnym języku polskim dotyczy przygotowania posiłków, np. przyrządzić sałatę), stąd zapewne przyrząd 'urządzenie, instrument, służący do wykonania pewnej czynności (do końca)'. We współczesnym języku polskim (za słownikiem B. Dunaja) przyrząd to złożone urządzenie techniczne służące do wykonywania określonej czynności. Przyrządy pomiarowe, celownicze, nawigacyjne. Nawet stosunkowo proste urządzenie, jeśli spełnia funkcję pomiarowo-kontrolną, jest przyrządem. Przykładowo wkrętak (in. śrubokręt) jest narzędziem, ale gdy jest on wyposażony w kontrolkę napięcia (tzw. fazer, wskaźnik napięcia), jest już przyrządem. Tym bardziej przyrządem jest np. amperomierz, omomierz, woltomierz itp.

Odpowiednikiem semantycznym (mającym szerszy zakres znaczeniowy) polskiego przyrząd jest w języku bułgarskim rzeczownik nрuбop, mający 
w polszczyźnie odpowiednik (obecnie w l. mn.) przybory. Według słownika współczesnego bułgarskiego języka literackiego ${ }^{13}$ прибор posiada następujące znaczenia: 1. апарат, уред, предмет, приготвен за извършване на някаква работа 'aparat, urządzenie, przedmiot, służący do wykonania pewnej pracy'. Електроизмервателен прибор. Навигационни прибори. 2. комплект от предмети, предназначени за определена цел 'komplet przedmiotów przeznaczonych dla określonego celu'. Прибор за брбснене. Прибори за ядене. Тоалетни прибори. 3. [zawęż.] комплет от предмети, които се употребяват при ядене за едно лице 'komplet przedmiotów, używanych przez jedną osobę do jedzenia, sztućce'. Чува то, че горе, в салона за ядене, дрвнкат вече приборите, нареждат се вкусните ядения. Тя си имаше своя отделен прибор и сядаме все на едно и също място. Pierwsze spośród wyżej wymienionych znaczeń odpowiada polskiemu przyrzad, natomiast pozostałe dwa - przybory. Znaczenie polskiego wyrazu przybory słownik Dunaja definiuje następująco: [brak 1. poj.] rzeczy, przedmioty o różnym stopniu skomplikowania technicznego, służące do wykonywania określonych czynności, operacji, tworzące zwykle zestaw, komplet, przybory techniczne, toaletowe, przybory do pisania. Słownik języka polskiego pod red. Mieczysława Szymczaka interesujący nas wyraz zamieszcza w liczbie pojedynczej (przybór) jako hasłowy i definiuje następująco: 1 . [brak l. mn.] wezbranie wody w jeziorze, rzece. 2. [zwykle w l. mn.] przedmioty użytkowe, służące do wykonywania czegoś, tworzące pewien komplet; narzędzia, przybory toaletowe, przybory do kreślenia, pisania, przybory żeglarskie, nawigacyjne, przybory techniczne. Co się tyczy pierwszego znaczenia, to słownik B. Dunaja zamieszcza je jako odrębne hasło. Jest to słuszne, albowiem znaczenia są zupełnie inne. Poza tym w pierwszym znaczeniu wyraz jest singulare tantum, $w$ drugim - plurale tantum. W języku polskim pierwotnie $\mathrm{w}$ interesującym nas znaczeniu występował ten rzeczownik w liczbie pojedynczej - przybór 'komplet narzędzi (akcesoriów) potrzebnych do określonego celu, ekwipunek', które zostało zastąpione później przez formę l. mnogiej przybory (Bańkowski II 929). Pochodzi od nomen deverbale *borz 'branie' (z ie. *bhor-o-s) z przedrostkiem przy- $(<$ pri-), czyli pierwotnym znaczeniem byłoby 'zbiór, dobór', stąd 'zbiór (komplet) przedmiotów (służących do określonego celu)'. Od tegoż nomen deverbale pochodzi także ros. Haбop 'komplet, zestaw'. Czasownik brać (ogólnosłowiański) < ps. *bbrati, * bero (w językach słowiańskich znaczenie 'brać powstało prawdopodobnie najpierw w czasownikach przedrostkowych,

13 Речник на съвременния български книжовен език, ред. Ст. Романски, т. 1-3, София 1955-1959 (dalej: RSBKE). 
por. zebrać, zabrać) ma odpowiedniki niesłowiańskie, m.in. germańskie, por. niem. gebähren 'rodzić, szwedz. bära 'nieść, nosić, przynosić, znosić (w jedno miejsce)', norw. baere 'nosić, znosić (wytrzymywać)', ang. bear, hol. baren; także bałtyckie: lit. berti 'sypać, bírti 'sypać się, także łac. ferō 'nieść, grec. $\varphi \varepsilon \varepsilon \varepsilon \imath v$, sanskr. bhr- 'nieść, trzymać, utrzymywać, posiadać, pożyczać, ofiarować, zabierać, podnosić.' Pochodzi z pie. *bher- 'unosić, nieść' (Bańkowski II 70-71; Boryś SE 37).

W bułgarszczyźnie w znaczeniu 'instrumentum' funkcjonuje także rzeczownik сечивò. Słownik Romanskiego (RSBKE) definiuje go następująco: занаятчийско или земеделско ръчно оръдие, инструмент 'ręczne narzędzie rzemieślnicze lub rolnicze'. На тезгяха стояха чукчета, рендета, а по диреиите бяха закачени триони, тесли, бичкия и други сечива. В бглите на стаята и на една ниска масичка, дори на рогозката ... бяха наслагани в безредие резбарски сечива. Зидарски сечива. Златарски сечива. Rzеczownik ten pochodzi od czasownika секa, który jest ogólnosłowiański: por. pol. siec, czes. síci // síct, ros. ceษb, sch. sjèći, sijèčēm 'siec, rąbać, krajać, siekać,

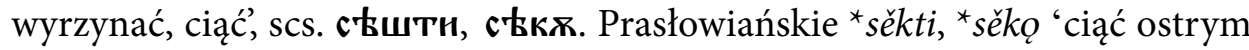
narzędziem'. Ma dokładny odpowiednik (z długim rdzennym è) w litewskim $i$-sèkti 'wciąć', iš-sèkti 'wydłubać'; w innych językach indoeuropejskich odpowiedniki z krótkim rdzennym ĕ: łac. secāre 'ciąć, obcinać, rozcinać. Wywodzi się z pie. 'sek- 'obrabiać ostrym narzędziem' (Boryś SE 545). Przyrostek -uвo w języku bułgarskim jest jednym spośród licznych formantów tworzących nazwy przedmiotów, narzędzi, substancji i wyrobów od podstawy czasownikowej, por. гориво, вариво, печиво, плетиво. Etymologicznie сечиво оznaczałoby 'ostre narzędzie do obróbki skrawaniem, krojenia, siekania, rąbania' (por. pol. siekiera = bułg. брадвa) i w praktyce wyrazu tego używa się w języku bułgarskim prawie wyłącznie dla nazwania tego typu narzędzi (inne to инструменти).

Język bułgarski zna również zupełnie obcy polszczyźnie (i większości pozostałych języków słowiańskich $\mathrm{z}$ wyjątkiem macedońskiego i serbsko-chorwackiego) rzeczownik aлàm. Słownik BAN (RBE) zamieszcza go z kwalifikatorem dial. i tłumaczy poprzez synonimy: занаятчийски инструмент, оръдие, сечиво (semantycznym odpowiednikiem polskim jest narzędzie). Znaczenie zilustrowano przykładem: Ранобудни майстори зидари от Дебърско в своите бозови салтамарки, прехвгрлили през рамо збмбилите, ... в които бяха сложили алатите си, бързаха към постройката, на която работеха. W słowniku też zamieszczono kolektywne znaczenie tegoż rzeczownika (użytego w l. poj.): всички занаятчийски инструменти, оръдия, сечива като цяло 'wszystkie narzędzia rzemieślnicze jako jedna 
całość. Przykład: Бедни пюде молеха Чауша да не им взема нивата, да не им взема алата или дюкяна, за да не останат без работа. Wyraz ten pochodzi z tureckiego alât 'instrumenty, przyrządy', który jest formą liczby mnogiej od alet 'narzędzie, instrument, aparat, przyrząd'. Turecka nazwa pochodzi $\mathrm{z}$ arabskiego (BER I 8) ${ }^{14}$.

W przeciwieństwie do bułgarskiego, gdzie rzeczownik aлam jest dialektyzmem, w języku macedońskim jest on normalną i powszechnie używaną nazwą 'narzędzia. Odnotowany jest on przez słownik języka macedońskiego ${ }^{15}$. Znany jest on także w języku serbsko-chorwackim. Słownik Vuka Karadži$\mathrm{cia}^{16}$ zamieszcza nazwę àlāt, tłumacząc przez niem. 'das Werkzeug' oraz przez łac. 'instrumenta'. Ilustruje go przykładem: Bez alata nema zanata 'dosł.: bez narzędzi nie ma rzemiosła'. Słownik ten podaje też rzeczownik alàtljika, tłumacząc przez niem. 'ein einzelnes Werkzeug' oraz łac. 'instrumentum'. Oznacza to, że àlät ma znaczenie kolektywne 'zestaw, komplet narzędzi, wszystkie narzędzia'. Oczywiście język serbsko-chorwacki zna także słowiańską nazwę oruđe, która ma znaczenie 'narzędzie, przyrząd, sprzęty, utensylia' a także 'działo' ${ }^{17}$. Słownik JAZU ${ }^{18}$ tłumaczy oruđe przez łac. 'instrumentum, organum' oraz poprzez sch. alat i opisowo: ono, što treba zanatliji, radniku ili težaku za negov posao 'to, co potrzebne jest rzemieślnikowi, robotnikowi lub rolnikowi do jego pracy'. Słownik też podaje inne znaczenie tegoż rzeczownika: sprava, naprava, t. j. ono, što služi za drugi kakav posao a ne baš zanatlijski ili težački 'rzecz, urządzenie, które służy dla kogoś, kto nie jest rzemieślnikiem czy rolnikiem do wykonywania pracy'. Ilustruje kilkoma przykładami: pjesničko oruđe, koje mi harpom zovemo (w tym kontekście jest to 'instrument muzyczny'). Podobnie: pjevači pjevaju uz oruđa muzička. Bojno oruđe 'narzędzie walki, oręż. Oczywiście język serbsko-chorwacki zna także rzeczownik instrumen(a)t, który posiada następujące znaczenia: 1. oruđe, pomagalo, alatka 'narzędzie, przyrząd pomocniczy'. Przykład: Doktori su sobom poneli instrumente i sanitetski materijal. W tym kontekście jest to instrument lekarski. 2. muzička sprava 'instrument muzyczny'. Gudački instrumenat. 3. dokumenat, isprava,

${ }^{14}$ Zob. także L. A n to now i c z-B a u e r, A. D u biń ski, Słownik turecko-polski i polsko-turecki, Warszawa 1983, s. 20-21.

${ }^{15}$ Речник на македонскиот јазик, ред. Б. Кон ески, т. 1-3, Скопје 1961-1966 (dalej: RMJ).

${ }^{16}$ Српски рјечник истумачен юемачкијем и латинскијем ријечима, скуп. и изд. Вук С теф. К а р а ић, 4. изд., Београд 1935.

${ }^{17}$ Za: V. Fr a n čić, Słownik serbsko-chorwacko polski, t. I-II, Warszawa 1987. Oruđe notowane jest przez wszystkich leksykografów, z wyjątkiem Vuka Karadžicia (jak podaje P. Skok).

${ }^{18}$ Rječnik hrvatskoga ili srpskoga jezika, t. I-XXIII, JAZU, 1860-1986 (dalej: RJAZU). 
propis 'dokument, dowód, przepis, zarządzenie'19. Słownik JAZU dokumentuje ten rzeczownik jedynie $\mathrm{w}$ tym ostatnim znaczeniu.

W języku serbsko-chorwackim również występuje rzeczownik pribor, którego zakres znaczeniowy jest znacznie większy niż w języku polskim, a także niż w bułgarskim. Posiada on znaczenia: 1. skup naprava, koju služe za određenu svrhu 'zestaw przedmiotów, służących do określonej czynności': brijaći pribor, zidarski pribor, pribor za jelo. 2. med. skup organa, koji imaju određenu funkciju 'zbiór narządów, które mają określoną funkcję. Przykład: pribor za disanje 'układ oddechowy' (RMS). To znaczenie medyczne nie występuje w innych językach słowiańskich ${ }^{20}$.

Język serbsko-chorwacki zna także inne rzeczowniki o znaczeniu 'instrumentum' Jednym z nich jest sprava: 1 . oruđe, koje služi za izvođenje kakvih radova, naprava, alatka, alat 'narzędzie, które służy do wykonywania pewnych prac'; b. instrumenat sa specijalnim mehanizmom, uređaj za izvođenje složenjih radnji 'przyrząd, urządzenie do wykonywania złożonych, specjalnych prac'; c. (tylko l. mn.) muzički instrumenti 'instrumenty muzyczne': Pjevaće sa spravama muzičkim. 2. pribor: lovačka sprava, a w l. mn. spràve 'przyrządy gimnastyczne'21.

Także rzeczownik naprava może mieć w języku serbsko-chorwackim to znaczenie. Słownik Maticy tłumaczy go następująco: 1. sprava, oruđe, aparat, uređaj 'przyrząd, narzędzie, aparat, urządzenie'. Przykład: Neka smiješna naprava za plašenje pticu; 2. pribor potreban za što, oprema, sprema 'przybory potrzebne do czegoś, urządzenie, sprzęt'; 3. odelo, odeća 'odzież'; 4. postupak 'postępowanie'. Słownik serbsko-chorwacki-polski V. Frančicia tłumaczy sch. naprava poprzez pol. przyrząd, forma, urządzenie, przybór ${ }^{22}$, narzędzie.

Serbsko-chorwackie nazwy naprava, sprava są derywatami od czasowników prefigowanych, pochodzących z podstawowego verbum pràviti, -ìm 'facere' (inne znaczenia: 'mówić, wypowiadać się, domagać się, zwłaszcza prawnie, skarżyć', daw. 'opowiadać, mówić), a to od przymiotnika pràv (ogólnosłowiański, także bałtosłowiański) 'verus' a także 'prosty, sprawny, właści-

19 Рјечник српскохрватског книжевног језика, t. I-VI, Novi Sad-Zagreb 1967-1976 (dalej: RMS).

${ }^{20}$ Warto też zwrócić uwagę na paralelę w polszczyźnie narzędzie : narząd.

${ }^{21}$ To ostatnie za: V. Fr a n č ić, Słownik serbsko-chorwacko polski, t. I-II, Warszawa 1987. Podstawowe spràva (l. poj.) tłumaczy na pol. 'narzędzie, przyrząd, maszyna, aparat'. Inne znaczenie (wg tegoż słownika) to 'wyprawa (panny młodej)'. Słownik Maticy (RMS) podaje je jako archaiczne, a słownik Vuka Karadžicia zaznacza, iż to ostatnie znaczenie występuje tylko w Dubrowniku.

${ }^{22} \mathrm{~W}$ języku polskim przybory to plurale tantum (autor Słownika jest Chorwatem). 
wy, odpowiedni, stosowny' (pierwotne znaczenie 'skierowany naprzód', czyli 'prosty'). Znaczenia czasowników przedrostkowych są wtórne ${ }^{23}$.

Oprócz rzeczownika aлam język macedoński zna także inne nazwy oznaczające 'instrumentum'. Jedną z nich jest инструмент, mający w tym języku następujące znaczenia: 1. справа, орудје 'narzędzie', 2. музичка справа 'instrument muzyczny', 3. (przen.) средство за постигање на некаква цел 'środek do osiągnięcia pewnego celu' (RMJ). Zakres znaczeniowy mac. инструмент jest więc zbliżony do zakresu znaczeniowego tego wyrazu w języku bułgarskim. Opydue posiada także te same znaczenia, co w języku bułgarskim: 1. предмет, инструмент за работа, алат 'narzędzie': Земјоделски машини и други орудија, 2. (przen.) средство за остварување, за постигање на нешто 'środek do osiągnięcia jakiegoś celu', 3. општ назив за артилериското оружје 'artyleria, działo, armata'.

Natomiast прибор w języku macedońskim posiada znacznie węższy zakres znaczeniowy niż w języku bułgarskim czy serbsko-chorwackim: комплет од предмети за извесна цел 'komplet przedmiotów do określonego celu': прибор за бричене, прибор за јадеюе. Jest więc pod względem zakresu znaczeniowego zbliżony do polszczyzny.

W języku macedońskim występuje także (znana w serbsko-chorwackim) nazwa справа, która jest (wg Słownika języka macedońskiego) synonimem takich rzeczowników, jak прибор, орудие, инструмент. Istnieje też złożenie гимнастички справи 'przyrządy gimnastyczne'.

$\mathrm{W}$ języku słoweńskim rzeczownik instrumènt oznacza ${ }^{24}$ : 1. zelo natančna priprava, ki se uporablja pri specializiranem strokovnem, znavstvenem delu 'specjalny przyrząd, wykorzystywany w celach pomiarowych, medycznych, naukowych', np. merilni instrument, kirurški instrument, optični instrument, 2. priprava za proizvajanje tonov, glasbilo 'instrument muzyczny', 3. (przen.) sredstvo, pripomoček za dosego določenega cilja 'środek, dla osiągnięcia jakiegoś celu'. Język ten zna także rzeczownik orodje mający ogólne znaczenie: predmet, ki se uporablja pri fizičnem delu 'narzędzie', kovinsko orodje, $z i$ darsko orodje, vrtnarsko orodje. Także odnotowano znaczenie przenośne tego rzeczownika 'środek (dla osiągnięcia celu)'. Znany jest także rzeczownik pribor. Język słoweński zna też rzeczownik glasbilo, oznaczający: priprava za proizvajanje tonov 'instrument muzyczny' igrati na glasbilo.

${ }^{23}$ Zob. P. Skok, Etimologijski rječnik hrvatskoga ili srpskoga jezika, t. III. Zagreb 1973, s. 26-27 a także Boryś SE 480.

${ }^{24}$ Slovar slovenskega knjižnega jezika, t. I-V, Ljubljana 1970-1991 (dalej: SSKJ). 
Dokładny odpowiednik formalny polskiego narzędzie występuje w języku czeskim. Słownik języka czeskiego F. Trávníčka ${ }^{25}$ podaje nářadí [coll. - hromad.] pomocné předměty, nástroje 'przedmioty służące do czegoś, instrumenty'. Podaje też przymiotnik nářad’ový w kontekście náradové cvičení 'gimnastyka na przyrządach'. Łacińska nazwa instrument jest w języku czezskim odnotowana przez słowniki, lecz normalnie używanym odpowiednikiem jest nástroj. Słownik F. Trávníčka nie tłumaczy znaczenia nazwy instrument, lecz daje synonim nástroj. Niemniej jednak zamieszcza derywaty od łacińskiej nazwy: instrumentalista zpracovatel skladby pro nástroje 'wykonawca muzyki instrumentalnej', instrumentista 'ts., instrumentarium, instrumentar (instrumentařka) pomocník podávající operatérovi nastroje 'osoba podająca operatorowi (chirurgowi) instrumenty', instrumentovati zpracováti skladbu pro nástroje 'wykonywać muzykę instrumentalną'. Z objaśnień znaczeń tych derywatów wynika, iż czes. nástroj jest właściwie dokładnym odpowiednikiem znaczeniowym pol. instrument (odnosi się do instrumentów muzycznych i medycznych - chirurgicznych), niemniej jednak Słownik czesko-polski J. Siatkowskiego i M. Basaja ${ }^{26}$ tłumaczy go zarówno przez 'narzędzie', jak i 'instrument' (zależnie od kontekstu). Inne znaczenie wyrazu nástroj to [przen.] pomocník, vykonavatel jeho vůle, záměru 'wykonawca czyjejś woli'. Słownik F. Trávníčka definiuje czes. nástroj jako 'předmět, kterým člověk zpracováva svůj pracovní předmět 'przedmiot, za pomocą którego człowiek wykonuje swoją pracę. Natomiast wyraz príbor ma w języku czeskim wąski zakres znaczeniowy i odnosi się (wg słownika F. Trávníčka) jedynie do przyborów do jedzenia, sztućców - nástroj(e) k jídlu (nůž, vidlička) - zdaniem F. Trávníčka jest to zapożyczenie $\mathrm{z}$ rosyjskiego. Autor podaje też derywat př́borník 'kredens' (w języku polskim przybornik ma inne znaczenie 'etui z przyborami kreślarskimi, przybornik rysunkowy'). Słownik czesko-polski tłumaczy př́bor następująco: 1. nakrycie stołowe, sztućce, 2. serwis, np. čajový (kávový) př́bor 'serwis do herbaty (kawy)'. W tym ostatnim kontekście odnotował też dla języka polskiego A. Bańkowski: przybór do kawy.

Także język słowacki zna odpowiednik pol. narzędzie - náradie [coll.] nástroje, pomôcky na prácu a inú činnost' 'urządzenia pomagające $\mathrm{w}$ pracy lub wykonywaniu innych czynności', np. záhradnicke náradie 'narzędzia ogrodnicze'. Odnotowano też go w znaczeniu: zariadenie, na kterým sa cvičí

${ }^{25}$ F. Travníček, Slovník jazyka českého, Praha 1952.

${ }^{26}$ J. Si a t kow ski, M. B a s a j, Słownik czesko-polski. Česko-polský slovník, Warszawa Praha 1991. 
'przyrządy gimnastyczne, sprzęt sportowy'. Rzeczownik inštrument $\mathrm{KSSJ}^{27}$ tłumaczy przez nazwę nástroj, który ma znaczenie: pomôcka na prácu, pracovný prostriedok, inštrument 'instrument (muzyczny, medyczny - np. chirurgiczny)', 'narzędzie', np. murársky nástroj, a także przenośne prostriedok na uskotočňovanie nejakej činnosti 'środek dla dokonania jakiejś czynności', byt' (slepým) nástrojom niekoho. Niemniej jednak Słownik słowacko-polski ${ }^{28} \mathrm{za}-$ mieszcza wyraz inštrument, tłumacząc jego znaczenie przez instrument i narzędzie, np. chirurgické inštrumenty, stavbáraske inštrumenty. Tenże słownik tłumaczy słc. nástroj przez pol. narzędzie, instrument (zarówno muzyczny, jak i chirurgiczny) a także przyrząd, np. presné nástroje oraz podaje znaczenie przenośne środek. Príbor (za KSSJ) w języku słowackim oznacza wyłącznie súprava načinia, ktorým jeme (lyžica, vidlička, nož) 'przybory do jedzenia, sztućce' (KSSJ). Słownik słowacko-polski tak samo tłumaczy ten wyraz - przez pol. sztućce (SSP UJ).

W języku górnołużyckim występuje strukturalny odpowiednik polskiego narzędzie - narjad, tłumaczone przez słownik H. Zemana ${ }^{29}$ jako 1. urządzenie, przykł. signalowy narjad, 2. zarządzenie, rozporządzenie. To ostatnie jest odpowiednikiem znaczeniowym bułgarskiego наредба. Słownik ten zamieszcza również wyraz narjada (femin.) oznaczający 'sprzęt gimnastyczny'.

$\mathrm{W}$ języku rosyjskim rzeczownik инструмент ma następujące znaczenie: орудие, снаряд, прибор, сручье, струмент - всякаго рода ручное пособие или устройство для какой-либо работы, начиная од ножа и топора, до компаса и секстана 'każdego rodzaju ręczne narzędzie dla wykonywania jakiejś pracy, począwszy od noża, topora, skończywszy na np. kompasie, sekstansie ${ }^{30}$. Słownik podaje też przykład инструментальная музыка 'muzyka instrumentalna', co świadczy o tym, że rzeczownik ten oznacza też (w odpowiednim kontekście lub konsytuacji) 'instrument muzyczny’(SSRLJa). Opydue według tegoż słownika to: всякое вещественное и невещественное средство, все посредуючее между деятелем а делом; инструмент, снаряд, оружие, машина 'wszelki środek materialny bądź niematerialny, będący pośrednikiem pomiędzy wykonującym pracę a przedmiotem pracy’. Przykład: Кричный молот оружие и писючее перо оружие. Słownik także podaje drugie znaczenie [wojsk.] пушка и всякое крупное огневое оружие 'armata

${ }^{27}$ Krátky slovník slovenského jazyka, Bratislava 1989 (dalej: KSSJ).

${ }^{28}$ Z. Jurczak-Trojan, H. Mieczkowska, E. Orwińska-Ruziczka, M. Papi e r z, Słownik słowacko-polski, t. I-II, Kraków 1998 (dalej: SSP UJ).

${ }^{29}$ H. Z e m a n, Słownik górnołużycko-polski, Warszawa 1967.

${ }^{30}$ Словарь современного русского титературного языка, т. I-XVII, Москва-Ленинград 1948-1965 (dalej: SSRLJa). 
i wszelka broń palna o dużej sile rażenia, działo'. Odnotowano także liczne derywaty. Rzeczownik снаря̀d odnotowano nie jako oddzielne hasło, lecz jako derywat od czasownika снаряжать. Ten derywat oznacza: орудие, оружие, инструмент, машина, снасть, вещь как средство в ремесле, промысле, искусстве 'narzędzie, broń, instrument, maszyna, wszelka rzecz, będąca środkiem pracy w rzemiośle, przemyśle, sztuce. Przykład: Без снаряда щзо без рук. Слесарный, столярный снаряд. Czasownik снаряжа̀ть ma znaczenie 'wyposażać, uzbrajać, ekwipować'.

Język rosyjski zna też nazwę dla 'instrumentum' снасmb, odnotowaną przez Dala ${ }^{31}$, którą tłumaczy: орудие, снарядь, прибор, сбруя, инструмент, машина 'narzędzie, urządzenie, przyrząd, uzbrojenie, instrument, maszyna'. Przykład: Снасти лесника, зверолова. Снасти рыбака (сети, мережи, морды,$y \partial b \iota)$. W słowniku tym zaznaczono, że nazwa pochodzi od czasownika надо 'trzeba', a więc etymologiczne znaczenie byłoby 'to, co potrzebne (do czegoś)'. Analogicznie w języku bułgarskim używa się rzeczownika nompeбa, np. домашни потреби 'artykuły gospodarstwa domowego'. Rosyjskie надо pochodzi (wg M. Vasmera) od formy celownika i miejscownika rzeczownika staroruskiego надоба 'potrzeba' (Vasmer: III, 38). Rzeczownika прибор słownik Dala (Dal) nie zamieszcza jako oddzielne hasło, lecz wśród derywatów od czasownika прибирать i podaje takie przykłady jak: Столовыцй прибор. Письменный прибор. Чертежный прибор. Гранильный прибор. Natomiast bogato ilustruje go SSRLJa (SSRLJa, 11). Ten ostatni tłumaczy jego znaczenie następująco: 1. устройство, аппарат, предназначенный для управления машинами, установками, для регулирования технологических процессов, вычислений... 'urządzenie, aparat przeznaczony do sterowania maszynami, urządzeniami, do regulacji procesów technologicznych, obliczenia. Przykłady: Водомерный прибор. В нашем разпоряжении много приборов, контролирующих правильность полета: магнитньй компас, солнечный компас, радиокомпас, радиомаяк. 1а. специальное приспособление к станку, машине, транспортному устройству, выполняющее самостоятельную часть работы 'specjalne urządzenie dołączone do obrabiarki, maszyny, urządzenia, umożliwiające wykonanie osobnej czynności'. Прицельный прибор орудия. Упряжной прибор паровоза. Inne znaczenie ros. прибòp to: учебно-наглядное пособие, служащее для демонстрации какой-либо закономерности 'pomoce do nauczania poglądowego'. Przykład: Химический прибор. Rzeczownik ten posiada również znaczenie: комплект,

${ }^{31}$ В. Даль, Толковныци словарь живого великорусского языка, т. I-IV, Москва 1956 (dalej: Dal). 
набор предметов для какого-либо пользования 'komplet, zbiór przedmiotów służących do czegoś. Przykłady: Бритвенный прибор, Чайный прибор. Także występuje w znaczeniu: комплект, набор предметов, предназначенных для еды одному человеку 'zestaw przedmiotów służących do jedzenia dla jednej osoby, sztućce’. Накрыть стол на пять приборов. W języku rosyjskim rzeczownik ten także występuje w znaczeniu: комплект приклада и знаков различия к обмундированию 'komplet dodatków i dystynkcji do munduru': Золотые и серебрянные приборы офицеров.

W języku ukraińskim dosyć szerokim zakresem znaczeniowym charakteryzuje się rzeczownik прилад (l. mn. прйлади). Oznacza on pol. przyrząd, a także aparat, np. бізични прилади, авіаприладдя. Jako plurale tantum прила̀ддя оznacza on pol. przybory, nр. письмове приладдя, туалетне приладдя. Ukraińskie прибор zostało odnotowane jedynie przez Słownik ukraińsko-polski pod red. S. Hrapca i P. Zwolińskiego ${ }^{32}$ w znaczeniu przyrzad, przybory a także serwis, zastawa, np. чайний приборь, обід на десять приборів. Narzędzie w języku ukraińskim nosi nazwę знаряддя, nр. знаряддя виробництва, a przede wszystkim інструмент, nр. ріжучий інструмент. Słownik Hrinczenki ${ }^{33}$ tłumaczy ukr. знаряддя przez ukr. орудie. Tego ostatniego wyrazu nie podaje jako hasłowego. Także nie zamieszcza go Słownik ukraińsko-polski (SUP), chociaż daje derywat орудниŭ w kontekście [gram.] орудний відмінок 'narzędnik'. Prawdopodobnie орудіe jest w języku ukraińskim wyrazem nieużywanym. Rzeczownik інструмент w języku ukraińskim oznacza nie tylko zwykłe ręczne narzędzie, ale także odnosi się do instrumentów medycznych (zabiegowych): хірургічні інструменти і осzywiście do muzycznych: музичний інструмент. Знаряддя jest dokładnym odpowiednikiem polskiego narzędzie (jedynie przedrostki się różnią: ukr. 3Ha- // pol. $n a-)$.

Ukraińskie прилад jest nie tylko semantycznym odpowiednikiem polskiego przyrzą, ale także zauważa się paralelę strukturalną. W języku ukraińskim rad ma szeroki zakres znaczeniowy i jest odpowiednikiem znaczeniowym zarówno polskiego ład, jak i porządek. Według słownika Hrinczenki (Hrinč) jest odpowiednikiem takich rosyjskich wyrazów, jak порядок, устройство, строй. Stąd też podstawa słowotwórcza rad w języku ukraińskim jest odpowiednikiem podstawy rząd w polszczyźnie.

${ }^{32}$ Słownik ukrainsko-polski, red. S. H rabec, P. Zwoliński, Warszawa 1957 (dalej: SUP).

33 Словарь української мови, упор. Б. Гр ин чен ко, т. I-IV, Київ 1907-1909 (dalej: Hrinč). 
Północnosłowiańskie *ladヶ 'harmonijny, uregulowany układ czegoś, porządek', wschodniosłowiańskie także 'zgodność, zgoda, układ, umowa' jest pierwotnym nomen deverbale od ${ }^{\star}$ laditi (por. ładzić $-\mathrm{w}$ języku polskim pożyczka wschodniosłowiańska) 'doprowadzać do stanu uporządkowanego, uregulowanego, harmonijnego, naprawiać reperować' ma pewne odpowiedniki bałtyckie: lit. lúodyti, -diju 'podszywać obuwie z łyka, łapcie'. Dokładna etymologia słowiańskiego ${ }^{*} l a d r$ jest niepewna ${ }^{34}$.

Nazwa ta jest znana także $\mathrm{w}$ języku białoruskim, gdzie ma postać прыла̀da. TSBLM ${ }^{35}$ objaśnia znaczenie tego rzeczownika następująco: 1. тэхнічнае прыстасаванне пры дапамозе якога выконываецца работа ці якое-н дзеяние 'urządzenie techniczne, za pomocą którego wykonuje się pracę czy jakąś czynność': Прылады пращы. 2. прыбор 'przyrząd'. 3. (zwykle w l. mn.) камплект прадметаў для выманання аднаго працэсу, напрамку работ 'komplet przedmiotów do wykonania pewnego procesu, etapu praсу, przybory’: Рыєбалоўныя прылады. Tо ostatnie znaczenie jest odpowiednikiem polskiego przybory. W języku białoruskim npыбòp oznacza: набор, прылад дла чаго-н 'komplet, zestaw do czegoś', np. Чарнылны прыбор, Чайны прыбор a także: прыстасаванне, спецыяльнае ўстройства, апарат для выканання якой-н работы, рэгулявання, кантролю и пад. 'specjalne urządzenie, przyrząd do wykonywania pewnej pracy, regulacji, kontroli itp.: Вымяральны прыборы, Награвальныя прыборы. Tо ostatnie znaczenie odpowiada polskiemu przyrząd.

Język białoruski zna także wyraz інструмѐнm, który ma następujące znaczenia: 1. прылада для выканання якой-н работы 'przyrząd, narzędzie do wykonywania jakiejś pracy': Хірургічны інструмент, Сталярны інструмент. 2. сукупнасць такіх прилад 'zbiór takich narzędzi'; 3. музычны інструмент 'instrument muzyczny': Духавыя інструменты. 4. [przen.] сродак для засяганення чаго-н 'środek dla osiągnięcia czegoś. Przykład: Быць паслухмяным інструментам у чыіх руках (TSBLM). Pierwsze znaczenie odpowiada zarówno polskiemu instrument, jak i narzędzie, drugie to pol. przybory.

Należałoby tu dodać, iż w języku rosyjskim także istnieje rzeczownik прилад (приладка), tyle, że - według słownika Dala (Dal) - jest to nomen deverbale od czasownika приладить 'przygotować, naprawić, doprowadzić do porządku, sprawności'.

${ }^{34}$ Zob. F. Sław ski, Słownik etymologiczny języka polskiego, t. IV, s. 416-417, 423-424, a także Boryś SE 293.

35 Тлумачалны слоўнік беларускай літаратурнай мовы, ред. М.Р. Суднік, Мінск 1999 (dalej: TSBLM). 
Podsumowując, można stwierdzić, iż oprócz wyrazu instrument pochodzenia łacińskiego, który w językach słowiańskich jest najbardziej rozpowszechniony (chociaż w czeskim i słowackim używa się zamiast niego nastroj), mającego różny zakres znaczeniowy w poszczególnych językach słowiańskich, duży obszar Słowiańszczyzny obejmuje nazwa kontynuująca ps. * pri-borz, przy czym jej zakres znaczeniowy jest bardzo zróżnicowany w poszczególnych językach słowiańskich. Stara słowiańska nazwa *orǫdoje w większości języków słowiańskich (bułgarski, macedoński, serbsko-chorwacki, słoweński, rosyjski, ukraiński) ma znaczenie 'instrumentum', w części języków oprócz znaczenia 'instrumentum' ma znaczenie 'działo, armata', w niektórych nie występuje w ogóle, natomiast w polszczyźnie ma zupełnie inne znaczenie. Nazwa kontynuująca ps. ${ }^{\star} n a-r e ̨ d \tau$ występuje we wszystkich językach zachodniosłowiańskich, a także (z dodatkowym przedrostkiem $s-/ z$-) w rosyjskim (снаряд) i ukraińskim (знаряддя). Wyłącznie polska jest nazwa kontynuująca ps. ${ }^{*}$ pri-rędz, mająca w języku ukraińskim i białoruskim odpowiednik będący kontynuatorem ps. ${ }^{*}$ pri-ladz ( ${ }^{*} l a d z$ jest wschodniosłowiańskim odpowiednikiem semantycznym ${ }^{\star}$ ręd ). Nazwa pochodząca $z$ tur. alât jest bałkanizmem leksykalnym, odnotowanym wyłącznie w językach Słowian bałkańskich (bułgarski, macedoński, serbsko-chorwacki). Pozostałe nazwy dla 'instrumentum', wymienione w artykule, nie są wspólne, lecz występują jedynie w poszczególnych językach słowiańskich.

\section{Names for instruments, tools, devices and accessories in Slavonic languages}

\section{(Summary)}

This article is devoted to the names for 'instruments', 'tools', 'devices' and 'accessories' in Slavonic languages. As it was described in this paper, there is no common name, which is an equivalent of Latin 'instrumentum' in Slavonic languages. The name, coming from Latin instrumentum, is known in the majority of the languages (except Czech and Slovak), but its scope of the meaning is not the same. In Polish it concerns only musical and medical (mainly surgical, dental, laryngological) instruments, but for instance in Bulgarian and Macedonian it is also used in the meaning 'tool' (sometimes also in Serbo-Croatian). In Slovenian it is used both in the meaning 'musical 
instrument', but also 'special device, used in medical, scientific and measurement purpose. This name has also a wide range of meaning in the EastSlavonic languages, especially in Russian (concerns not only to musical and medical (surgical) instruments, but also to any tool, used by craftsmen).

The name, continuing ${ }^{*}$ pri-borz is known in the majority of Slavonic languages, but their semantic scope is different (the largest is in Serbo-Croatian). An Old Slavonic word *orodrje in the majority of the Slavonic languages has the meaning 'tool, instrument', in some languages means 'canon', but in Polish it has quite different meaning (for instance, Orędzie Prezydenta RP). The noun, continuing ${ }^{\star} n a-r e ̨ d z$ is present in each West-Slavonic language, and - with a preffix - also in the East Slavonic. The noun, coming from the ${ }^{*}$ pri-rędr, exists only in Polish, but it has an equivalent ${ }^{*}$ pri-lads in Ukrainian and Byelorussian. The word, origins from Turkish alât is a lexical Balkanism, noticed only in the languages of Balkan Slaves (Bulgarian, Macedonian, Serbo-Croatian). Other names for 'instruments, tools, devices, accessories', described in this article, are not common, and exist only in separate languages. 